\title{
Subclassification of Small for Gestational Age Children with Persistent Short Stature: Growth Patterns and Response to GH Treatment
}

\author{
Wietske Ester ${ }^{a}$ Ellen Bannink ${ }^{a}$ Marije van Dijk ${ }^{a}$ Ruben Willemsen ${ }^{a}$ \\ Danielle van der Kaay ${ }^{a}$ Maria de Ridder ${ }^{b}$ Anita Hokken-Koelega ${ }^{a}$ \\ a Department of Pediatrics, Division of Endocrinology, Erasmus MC-Sophia Children's Hospital, and \\ ${ }^{b}$ Department of Epidemiology and Biostatistics, Erasmus MC, Rotterdam, The Netherlands
}

\section{Key Words}

Small for gestational age $\cdot$ Postnatal growth $\cdot$ Growth

hormone treatment $\cdot$ Head circumference

\begin{abstract}
Aim: We determined whether subclassification of short small for gestational age (SGA) children according to birth anthropometrics could delineate different patterns in gestation, delivery, postnatal growth, response to growth hormone (GH) treatment and parental height. Methods: 201 short SGA children were divided into three groups, $S G A_{L}$, $S G A_{L+W}$ and $S G A_{L+W+H C}$, according to birth length (L), weight (W) and head circumference $(\mathrm{HC}) \leq-2.00$ standard deviation score (SDS). Results: $\mathrm{SGA}_{\mathrm{L}+\mathrm{W}+\mathrm{HC}}$ children were born after the shortest gestational age and more often by caesarean section than $S_{G A}$ children (36.3 vs. 38.1 weeks, 68.4 vs. $24.4 \%) . S G A_{L+W}$ children had an intermediate pattern and experienced most gestational hypertension $(p=0.01)$. At birth, $\mathrm{SGA}_{\mathrm{L}+\mathrm{W}+\mathrm{HC}}$ children were shorter than $\mathrm{SGA}_{\mathrm{L}}$ or $\mathrm{SGA}_{\mathrm{L}+\mathrm{W}}(-4.12$ vs. -2.67 and -3.72 SDS, $p \leq 0.001$ ). During the first 3 years of life, $\mathrm{SGA}_{\mathrm{L}+\mathrm{W}+\mathrm{HC}}$ children exhibited an increased growth in

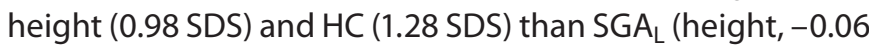
SDS; HC, -0.30 SDS) and SGA $\mathrm{L}_{+\mathrm{W}}$ (height, $0.62 \mathrm{SDS} ; \mathrm{HC},-0.31$ SDS). However, HC SDS remained smaller for $S G A_{L+W+H C}$ than the other groups at age 3 . The groups did not differ in growth response during $\mathrm{GH}$ treatment. $S G A_{L}$ children tended to
\end{abstract}

have shorter parents and target height than $\mathrm{SG}_{\mathrm{L}+\mathrm{W}+\mathrm{HC}}$ children. Conclusions: Our study shows that subclassification of short SGA children might be a useful method for investigating SGA children as the subgroups revealed a different gestation, delivery and postnatal growth pattern. Response to $\mathrm{GH}$ treatment was not different between the groups.

Copyright $\odot 2007$ S. Karger AG, Basel

\section{Introduction}

Small for gestational age (SGA) is the term used to describe a group of children born with a birth weight and/or birth length below the normal range of a reference population, corrected for gestational age at birth. Since reduced size at birth may result from any number of fetal, maternal, placental or demographic influences, children born SGA comprise a heterogeneous group with a broad spectrum of clinical characteristics. While many children born SGA achieve sufficient growth to normalize their stature by 2 years of age, approximately $10-15 \%$ maintain a height $<-2$ standard deviation scores (SDS) and continue to be short throughout adolescence and adulthood [1]. Furthermore, in a population-based postnatal growth study of 3,650 infants, of whom $8.1 \%$ were classified SGA according to their birth weight and birth length SDS, children born both short and light for gesta-

\section{KARGER}

Fax +4161306 1234 E-Mail karger@karger.ch www.karger.com (c) 2007 S. Karger AG, Basel

0301-0163/08/0692-0089\$24.50/0

Accessible online at:

www.karger.com/hre
Wietske Ester

Erasmus MC-Sophia Children's Hospital, Ee2183

Dr. Molewaterplein 50

NL-3015 GE Rotterdam (The Netherlands)

Tel. +31 104088 292, Fax +31 104089 382, E-Mail w.ester@erasmusmc.nl 
tional age were found to be shorter as adults than those born either short or light [2].

Short SGA children appear to benefit from growth hormone $(\mathrm{GH})$ treatment in terms of height increment. However, even after accounting for differences in parental height, age and duration of treatment, there appears to be a wide variation in the response to $\mathrm{GH}$ treatment that has been difficult to explain. The recent European approval of GH therapy to improve growth in short SGA children highlights the clinical relevance of ascertaining which short SGA children are most likely to benefit from treatment because potentially 23,000 European children meet the criteria for GH therapy annually [1-3]

We have previously demonstrated that mean head circumference $(\mathrm{HC})$ is significantly smaller $(\mathrm{p}<0.001)$ in short SGA children with a reduced birth weight and birth length ( $\leq-2.00$ SDS) than in short SGA children born with merely a short birth length ( $\leq-2.00$ SDS) [4]. The objective of this study was to determine whether subclassification of short SGA children according to their birth anthropometrics could delineate differences in gestation, type of delivery, postnatal growth, response to GH treatment and parental height.

\section{Methods}

\section{Patients}

Data was evaluated of 201 SGA children with persistent short stature who were participating in prospective cohort trials evaluating the effect of GH treatment [4-9]. SGA was defined as a birth length $\leq-2.00$ SDS [10]. Persistent short stature was defined as a height $\leq-2.00$ SDS at the age $\geq 3$ years [11]. Children were divided into three groups based on anthropometrics at birth: group $1 \mathrm{com}-$ prised children with reduced birth length $(\leq-2.00$ SDS) and normal birth weight and HC (SDS $>-2.00)\left(S_{\mathrm{LA}}\right)$, group 2 comprised children with reduced birth length and weight $(\leq-2.00 \mathrm{SDS})$ and normal HC (SDS >-2.00) $\left(\mathrm{SGA}_{\mathrm{L}+\mathrm{W}}\right)$, and group 3 included children with reduced birth length, weight and $\mathrm{HC}$ (SDS $\leq-2.00$ ) $\left(\mathrm{SGA}_{\mathrm{L}+\mathrm{W}+\mathrm{HC}}\right)$ [10]. All children fulfilled the inclusion criteria of being Caucasian and having an uncomplicated postnatal period. Children with severe chronic illness or endocrine disorders, chromosomal or genetic abnormalities, positive endomysial or transglutaminase antibodies, skeletal disorders, psychosocial dwarfism, and growth failure caused by other syndromes (except Silver-Russell syndrome), were excluded from the study.

The efficacy of 12 months GH treatment was evaluated in a subpopulation of 143 prepubertal children who were prepubertal at start and after 1 year of GH treatment. Prepuberty was defined as a bilateral testicular volume of $\leq 3 \mathrm{ml}$ for boys and Tanner stage M1 for girls. Children receiving medication for induction or postponement of puberty were excluded from the analysis. The study protocol was approved by local Medical Ethics Committees and written informed consent was obtained from the parents/guardians of each child.

\section{Clinical Parameter}

Data regarding gestational age and birth measurements were retrieved from medical records of 201 children. Maternal medical records of 120 children were traced for the type of delivery. Data regarding gestational hypertension, smoking (by mother, father or both) and use of alcohol were retrieved by questionnaires. Postnatal growth patterns from birth to 3 years of age were assessed using growth measurements from primary healthcare records, hospital records and baseline data from GH treatment studies of all 201 children. All measurements were plotted on a growth chart per child and checked for outliers to reduce within and between observer errors.

Ponderal index was calculated by ((birth weight in grams/ birth length in $\left.\mathrm{cm}^{3}\right) \times 100$ ) and expressed as SDS [12]. Body mass index (BMI) was calculated by (weight in $\mathrm{kg} / \mathrm{height}$ in $\mathrm{m}^{2}$ ) and SDS calculated according to Dutch reference values [11]. A measure for birth head size compared to length was obtained by subtracting birth head circumference SDS from birth length SDS. Height, weight, $\mathrm{HC}$ and sitting height were measured at start and after 1 year of GH treatment according to standardized methods $[4,5]$. Sitting height/standing height ratios for age were expressed as SDS using Dutch reference values [12]

Parental heights of 160 mothers and 157 fathers were assessed using a Harpenden stadiometer and expressed as SDS using Dutch reference values [13]. Target height (TH) SDS was calculated using Dutch reference values according to the formula: $1 / 2 \cdot($ Height father + Height mother +13$)+4.5$ for boys and $1 / 2 \cdot$ (Height father + Height mother -13$)+4.5$ for girls, where the addition of $4.5 \mathrm{~cm}$ represents the secular trend [11]. During GH treatment, biosynthetic $\mathrm{GH}$ was injected subcutaneously once daily at a dose of $1-2 \mathrm{mg} / \mathrm{m}^{2}$ body surface area/day.

Statistical Analysis

Anthropometric data were analyzed from birth until 3 years of age and before and after 12 months GH treatment. Analyses from birth to 3 years of age were performed on the total cohort of 201 children by univariate analysis of variance (ANOVA). Absolute birth size was adjusted for sex and gestational age to adjust for prematurity. Anthropometric SDS up to 3 years of age was also corrected for gestational age. The standard deviation (SD) of the adjusted means was approximated by $\mathrm{SD}=\mathrm{SE} \cdot \sqrt{\mathrm{n}}$. The $\chi^{2}$ test was used to analyze data on delivery and gestational factors.

A subgroup analysis on the effect of GH treatment on growth was performed in a group of 143 prepubertal children. Analysis of the growth response was performed by using ANOVA. Baseline measurements were corrected for age at start of GH treatment, as covariate in ANOVA. The growth response during 12 months of $\mathrm{GH}$ treatment was adjusted for $\mathrm{GH}$ dose and age at start of $\mathrm{GH}$ treatment, also as covariate in ANOVA. Standard deviations of the adjusted means were approximated by $\mathrm{SD}=\mathrm{SE} \cdot \sqrt{ } \mathrm{n}$. Parental and target heights were compared by using ANOVA. Parental heights were compared to 0 SDS by one-sample $t$ test.

If an overall test comparing the three groups was significant ( $\mathrm{p} \leq 0.05$ ), post-hoc tests with Bonferroni correction were performed. Statistical tests were performed using SPSS 11.0 Package (SPSS Inc., Chicago, Ill., USA). 
Table 1. Baseline characteristics of the total study population and the short SGA groups

\begin{tabular}{|c|c|c|c|c|c|c|}
\hline & & Total & $\mathrm{SGA}_{\mathrm{L}}$ & $\mathrm{SGA}_{\mathrm{L}+\mathrm{W}}$ & $\mathrm{SGA}_{\mathrm{L}+\mathrm{W}+\mathrm{HC}}$ & $\mathrm{p}$ value* \\
\hline Sex & boys/girls & $109 / 92$ & $36 / 31$ & $35 / 35$ & $38 / 26$ & 0.55 \\
\hline GA & weeks & $36.8 \pm 3.5$ & $38.1 \pm 3.1$ & $36.0 \pm 3.7$ & $36.3 \pm 3.7$ & $0.0004^{\mathrm{a}}$ \\
\hline \multirow[t]{2}{*}{ Birth length } & $\mathrm{cm}$ & $41.6 \pm 4.9$ & $42.8 \pm 2.1$ & $41.3 \pm 2.0$ & $40.7 \pm 2.0$ & $<0.000001^{\mathrm{a}}$ \\
\hline & SDS & $-3.50 \pm 1.30$ & $-2.67 \pm 0.54$ & $-3.72 \pm 1.30$ & $-4.12 \pm 1.42$ & $<0.00001^{\mathrm{a}}$ \\
\hline \multirow[t]{2}{*}{ Birth weight } & g & $1,921 \pm 716$ & $2,347 \pm 238$ & $1,762 \pm 234$ & $1,649 \pm 233$ & $<0.000001^{\mathrm{c}}$ \\
\hline & SDS & $-2.46 \pm 1.11$ & $-1.25 \pm 0.62$ & $-2.88 \pm 0.64$ & $-3.27 \pm 0.79$ & $<0.000001^{\mathrm{c}}$ \\
\hline \multirow[t]{2}{*}{ Birth HC } & $\mathrm{cm}$ & $31.5 \pm 3.0$ & $32.4 \pm 1.2$ & $32.4 \pm 1.2$ & $29.7 \pm 1.2$ & $<0.000001^{\mathrm{b}}$ \\
\hline & SDS & $-1.34 \pm 1.45$ & $-0.64 \pm 0.88$ & $-0.59 \pm 1.11$ & $-2.89 \pm 0.98$ & $<0.000001^{\mathrm{b}}$ \\
\hline Birth HC-Birth length & SDS & $2.16 \pm 1.71$ & $2.03 \pm 1.09$ & $3.13 \pm 1.89$ & $1.23 \pm 1.48$ & $<0.000001^{\mathrm{c}}$ \\
\hline \multirow[t]{2}{*}{ Height mother } & $\mathrm{cm}$ & $162.3 \pm 7.3$ & $160.6 \pm 9.0$ & $163.3 \pm 5.7$ & $163.0 \pm 6.3$ & 0.09 \\
\hline & SDS & $-0.97 \pm 1.17$ & $-1.24 \pm 1.45$ & $-0.80 \pm 0.93$ & $-0.85 \pm 1.01$ & 0.09 \\
\hline \multirow[t]{2}{*}{ Height father } & $\mathrm{cm}$ & $176.5 \pm 6.9$ & $176.2 \pm 7.7$ & $175.4 \pm 6.9$ & $178.4 \pm 5.7$ & 0.07 \\
\hline & SDS & $-0.82 \pm 1.04$ & $-0.87 \pm 1.15$ & $-0.99 \pm 1.03$ & $-0.53 \pm 0.85$ & 0.07 \\
\hline $\mathrm{TH}$ & SDS & $-0.51 \pm 0.86$ & $-0.66 \pm 0.86$ & $-0.52 \pm 0.87$ & $-0.29 \pm 0.83$ & 0.12 \\
\hline Birth length-TH & SDS & $-2.89 \pm 1.59$ & $-1.95 \pm 1.12$ & $-3.07 \pm 1.38$ & $-3.81 \pm 1.74$ & $<0.000001^{\mathrm{c}}$ \\
\hline Height-TH & SDS & $-2.61 \pm 0.85$ & $-2.53 \pm 0.85$ & $-2.63 \pm 0.85$ & $-2.72 \pm 0.83$ & 0.70 \\
\hline \multicolumn{7}{|l|}{ Type of delivery } \\
\hline \multirow[t]{2}{*}{ Vaginal } & $\%(\mathrm{n})$ & $52.5(63)$ & $75.6(34)$ & $45.9(17)$ & $31.6(12)$ & $0.0002^{c}$ \\
\hline & GA (weeks) & $38.9(2.1)$ & $39.1(2.2)$ & $38.6(2.5)$ & $38.6(1.4)$ & 0.66 \\
\hline \multirow[t]{2}{*}{ Acute CS } & $\%(\mathrm{n})$ & $13.3(16)$ & $11.1(5)$ & $13.5(5)$ & $15.8(6)$ & 0.82 \\
\hline & GA (weeks) & $37.1(3.3)$ & $35.8(4.3)$ & $37.4(3.9)$ & $37.8(1.7)$ & 0.61 \\
\hline \multirow[t]{2}{*}{ Elective CS } & $\%(\mathrm{n})$ & $34.2(41)$ & $13.3(6)$ & $40.5(15)$ & $52.6(20)$ & $0.001^{\mathrm{c}}$ \\
\hline & GA (weeks) & $35.0(2.8)$ & $37.5(2.1)$ & $33.8(2.3)$ & $35.1(2.9)$ & $0.02^{\mathrm{d}}$ \\
\hline \multicolumn{7}{|l|}{ Gestational factors } \\
\hline Hypertension & $\%(\mathrm{n})$ & $26.4(43)$ & $13.6(8)$ & $37.9(22)$ & $28.3(13)$ & $0.01^{\mathrm{d}}$ \\
\hline Smoking & $\%(n)$ & $49.7(42)$ & $50.0(25)$ & $46.0(23)$ & $53.3(24)$ & 0.77 \\
\hline Alcohol & $\%(n)$ & $7.4(12)$ & $3.4(2)$ & $12.3(7)$ & $6.5(3)$ & 0.18 \\
\hline
\end{tabular}

Values are means \pm SD unless indicated otherwise.

$\mathrm{GA}=$ Gestational age; $\mathrm{HC}=$ head circumference; $\mathrm{TH}=$ target height; $\mathrm{CS}$ = caesarean section; $\mathrm{SDS}=$ standard deviation score.

* Overall $\mathrm{p}$ value is presented by ANOVA for continuous and by $\chi^{2}$ test for categorical variables.

Post-hoc testing showed: ${ }^{a} \mathrm{SGA}_{\mathrm{L}}$ differed in comparison to the $\mathrm{SGA}_{\mathrm{L}+\mathrm{W}}$ and $\mathrm{SGA}_{\mathrm{L}+\mathrm{W}+\mathrm{HC}}$ groups; ${ }^{\text {b }} \mathrm{SGA} \mathrm{A}_{\mathrm{L}+\mathrm{W}+\mathrm{HC}}$ differed in comparison to the $\mathrm{SGA}_{\mathrm{L}+\mathrm{W}}$ and $\mathrm{SGA}_{\mathrm{L}}$ groups; ${ }^{\mathrm{c}}$ All groups differed significantly from each other; ${ }^{\mathrm{d}} \mathrm{SGA}_{\mathrm{L}}$ differed in comparison to the $\mathrm{SGA}_{\mathrm{L}+\mathrm{W}}$ group.

\section{Results}

\section{Birth Anthropometrics and Delivery}

As shown in table 1, there were statistically significant differences in anthropometric birth data between the $\mathrm{SGA}_{\mathrm{L}}, \mathrm{SGA}_{\mathrm{L}+\mathrm{W}}$ and $\mathrm{SGA}_{\mathrm{L}+\mathrm{W}+\mathrm{HC}}$ children, with the latter being the most severely affected ones with regard to all anthropometric data (table 1). Whereas $S_{G A} A_{L+W+H C}$ children were most proportional as expected, $\mathrm{SGA}_{\mathrm{L}+\mathrm{W}}$ children were most disproportional with a low birth length SDS in combination with a spared head in the normal range. $\mathrm{SGA}_{\mathrm{L}}$ children displayed an intermediate pattern. The type of delivery was different between groups. The majority (76\%) of the $\mathrm{SGA}_{\mathrm{L}}$ group was born after vaginal delivery in contrast to the $\mathrm{SGA}_{\mathrm{L}+\mathrm{W}}$ and $\mathrm{SGA}_{\mathrm{L}+\mathrm{W}+\mathrm{HC}}$ children (46 and $32 \%$, table 1). Whereas the frequency of acute caesarean sections was not different between the groups, the frequency of elective caesarean sections was different. Within the $\mathrm{SGA}_{\mathrm{L}+\mathrm{W}+\mathrm{HC}}$ group, $53 \%$ of children were born after an elective caesarean section in contrast to $41 \%$ of the $\mathrm{SGA}_{\mathrm{L}+\mathrm{W}}$ and $13 \%$ of the $\mathrm{SGA}_{\mathrm{L}}$ group.

Gestational hypertension occurred most frequently in the $\mathrm{SGA}_{\mathrm{L}+\mathrm{W}}$ children, in contrast with $\mathrm{SGA}_{\mathrm{L}}$ and $\mathrm{SGA}_{\mathrm{L}+\mathrm{W}+\mathrm{HC}}$ children (37.9 vs. 13.6 and $28.3 \%$ ). Smoking during pregnancy was highly prevalent $(49.7 \%)$ but did 


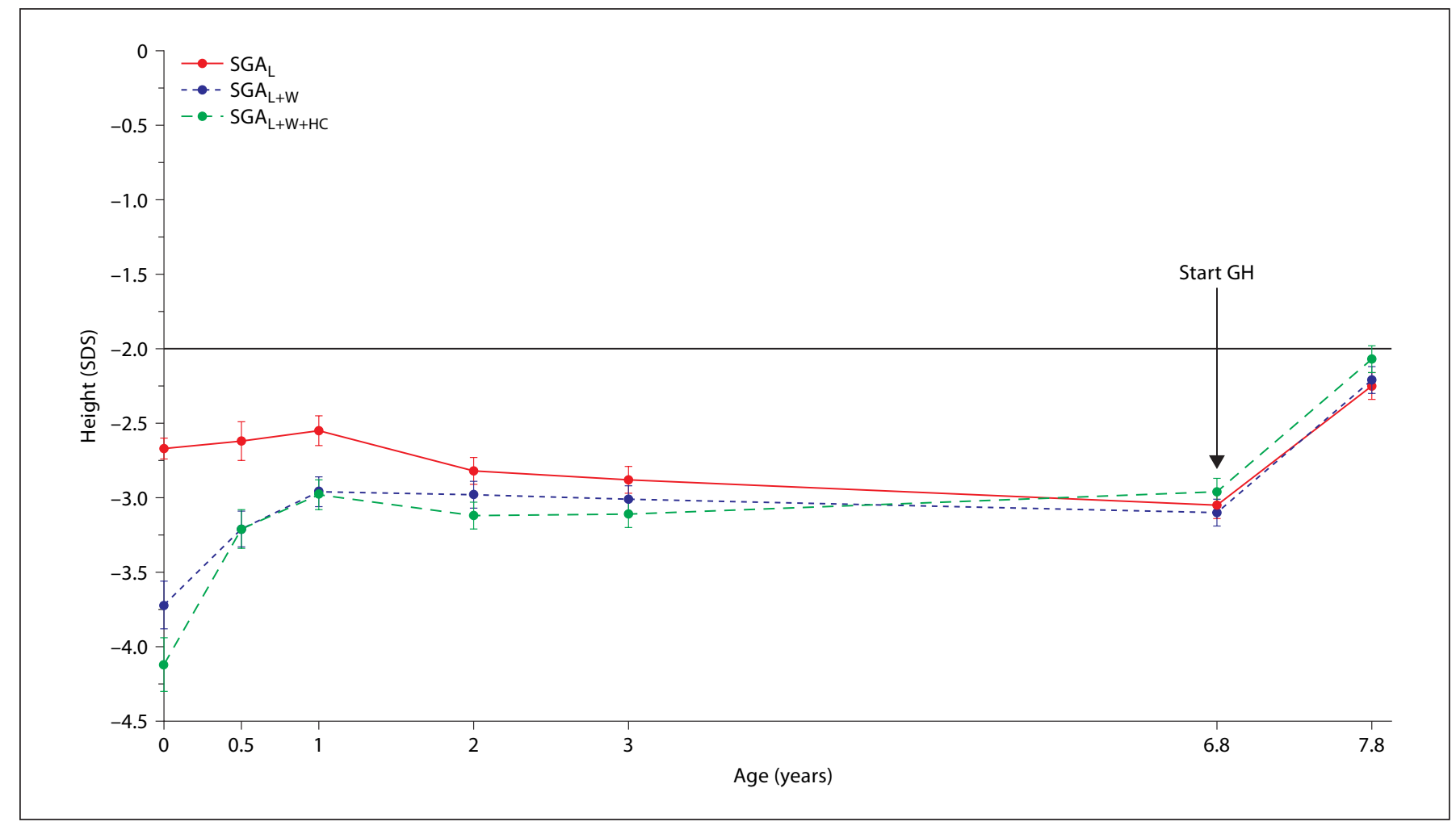

Fig. 1. Height (SDS) during the first 3 years of life and during 1 year of GH treatment for the short SGA groups. Data shown are means with standard errors.

differ between the groups. Alcohol use during gestation was reported in $7.4 \%$ of the total population and tended to be the most frequent in the $\mathrm{SGA}_{\mathrm{L}+\mathrm{W}}$ children, although not statistically different between the groups.

\section{Change in Height, Weight and HC during the First}

Three Years of Life

During the first 3 years of postnatal life, the extent of spontaneous growth differed between $S_{G A}$ children and children in the $\mathrm{SGA}_{\mathrm{L}+\mathrm{W}}$ and $\mathrm{SGA}_{\mathrm{L}+\mathrm{W}+\mathrm{HC}}$ groups (fig. 1; table 2). Growth in height was greatest for $\mathrm{SGA}_{\mathrm{L}+\mathrm{W}+\mathrm{HC}}$ children. At birth, children in the $\mathrm{SGA}_{\mathrm{L}+\mathrm{W}+\mathrm{HC}}$ group were shorter than those in the other groups (table 1), but by 6 months of age they had attained a height SDS that was similar to $\mathrm{SGA}_{\mathrm{L}+\mathrm{W}}$ children (-3.21 SDS) although they remained significantly shorter than $S G A_{L}$ children ( -2.62 SDS; $p=0.001$, table 2). In contrast, the height SDS of SGA $\mathrm{L}$ children remained virtually unchanged during this period (fig. 1).

Whereas the $\mathrm{SGA}_{\mathrm{L}}$ children had a substantial reduction in weight SDS from birth until the age of 3 years (fig. 2; table 2), $\mathrm{SGA}_{\mathrm{L}+\mathrm{W}}$ and $\mathrm{SGA}_{\mathrm{L}+\mathrm{W}+\mathrm{HC}}$ children maintained their weight SDS.

At birth, $\mathrm{HC}$ was by definition significantly $(\mathrm{p}<0.001)$ smaller in $\mathrm{SGA}_{\mathrm{L}+\mathrm{W}+\mathrm{HC}}$ children than in the $\mathrm{SGA}_{\mathrm{L}}$ and $\mathrm{SGA}_{\mathrm{L}+\mathrm{W}}$ children (table 1). During the first 6 months of postnatal life there was a substantial increase in HC SDS in $\mathrm{SGA}_{\mathrm{L}+\mathrm{W}+\mathrm{HC}}$ children from -2.9 SDS at birth to -1.9 SDS at 6 months followed by a further, albeit slower increase to -1.6 SDS at 3 years of age (fig. 3; table 2). Despite this marked increase, $\mathrm{HC}$ was at 3 years of age significantly smaller $(\mathrm{p}<0.001)$ in the $\mathrm{SGA}_{\mathrm{L}+\mathrm{W}+\mathrm{HC}}$ children as compared to children in the other two groups. For children born $\mathrm{SGA}_{\mathrm{L}}$ or $\mathrm{SGA}_{\mathrm{L}+\mathrm{W}}$, $\mathrm{HC}$ decreased slightly during the first 6 months of life and remained below their $\mathrm{HC}$ SDS at birth until the age of 3 years (table 2).

Ponderal index and BMI were investigated as measures for weight for height ratio at birth until the age of 3 . $\mathrm{SGA}_{\mathrm{L}}$ children had the highest ponderal index SDS at birth (3.86 SDS) in comparison with $\mathrm{SGA}_{\mathrm{L}+\mathrm{W}+\mathrm{HC}}$ children (0.17 SDS). SGA $\mathrm{L}_{\mathrm{W}}$ children showed an intermediate pattern $(0.66 \mathrm{SDS})$. Although $\mathrm{SGA}_{\mathrm{L}}$ children had the 
Table 2. Spontaneous growth during the first 3 years of life in the total population and the three groups of short SGA children

\begin{tabular}{|c|c|c|c|c|c|c|}
\hline & & Total & $\mathrm{SGA}_{\mathrm{L}}$ & $\mathrm{SGA}_{\mathrm{L}+\mathrm{W}}$ & $\mathrm{SGA}_{\mathrm{L}+\mathrm{W}+\mathrm{HC}}$ & p value* \\
\hline \multicolumn{7}{|l|}{ Height } \\
\hline 0.0 year & SDS & $-3.50 \pm 1.30$ & $-2.67 \pm 0.54$ & $-3.72 \pm 1.30$ & $-4.12 \pm 1.42$ & $<0.00001^{\mathrm{a}}$ \\
\hline 0.5 year & SDS & $-3.01 \pm 1.08$ & $-2.62 \pm 1.03$ & $-3.21 \pm 1.01$ & $-3.21 \pm 1.00$ & $0.001^{\mathrm{a}}$ \\
\hline 1.0 year & SDS & $-2.83 \pm 0.84$ & $-2.55 \pm 0.83$ & $-2.96 \pm 0.81$ & $-2.98 \pm 0.81$ & $0.004^{\mathrm{a}}$ \\
\hline 2.0 years & SDS & $-2.97 \pm 0.73$ & $-2.82 \pm 0.74$ & $-2.98 \pm 0.73$ & $-3.12 \pm 0.73$ & 0.07 \\
\hline 3.0 years & SDS & $-3.00 \pm 0.70$ & $-2.88 \pm 0.72$ & $-3.01 \pm 0.71$ & $-3.11 \pm 0.70$ & 0.20 \\
\hline Change $0-3$ & SDS & $0.50 \pm 1.37$ & $-0.06 \pm 1.23$ & $0.62 \pm 1.15$ & $0.98 \pm 1.19$ & $<0.00001^{\mathrm{a}}$ \\
\hline \multicolumn{7}{|l|}{ Weight } \\
\hline 0.0 year & SDS & $-2.46 \pm 1.11$ & $-1.25 \pm 0.62$ & $-2.88 \pm 0.64$ & $-3.27 \pm 0.79$ & $<0.000001^{\mathrm{c}}$ \\
\hline 0.5 year & SDS & $-2.74 \pm 1.28$ & $-2.08 \pm 1.16$ & $-2.95 \pm 1.14$ & $-3.21 \pm 1.13$ & $<0.00001^{\mathrm{a}}$ \\
\hline 1.0 year & SDS & $-2.75 \pm 1.14$ & $-2.14 \pm 1.07$ & $-2.94 \pm 1.05$ & $-3.19 \pm 1.05$ & $<0.00001^{\mathrm{a}}$ \\
\hline 2.0 years & SDS & $-2.78 \pm 1.02$ & $-2.21 \pm 0.96$ & $-2.94 \pm 0.94$ & $-3.21 \pm 0.94$ & $<0.00001^{\mathrm{a}}$ \\
\hline 3.0 years & SDS & $-2.82 \pm 0.96$ & $-2.34 \pm 0.92$ & $-2.96 \pm 0.91$ & $-3.19 \pm 0.90$ & $0.00001^{\mathrm{a}}$ \\
\hline Change 0-3 & SDS & $-0.36 \pm 1.10$ & $-1.04 \pm 0.98$ & $-0.10 \pm 0.99$ & $0.07 \pm 0.95$ & $<0.00001^{\mathrm{a}}$ \\
\hline \multicolumn{7}{|l|}{$\mathrm{HC}$} \\
\hline 0.0 year & SDS & $-1.34 \pm 1.45$ & $-0.64 \pm 0.88$ & $-0.59 \pm 1.11$ & $-2.89 \pm 0.98$ & $<0.000001^{\mathrm{b}}$ \\
\hline 0.5 year & SDS & $-1.40 \pm 0.94$ & $-0.98 \pm 0.84$ & $-1.31 \pm 0.83$ & $-1.91 \pm 0.83$ & $<0.000001^{\mathrm{c}}$ \\
\hline 1.0 year & SDS & $-1.26 \pm 0.89$ & $-0.92 \pm 0.81$ & $-1.10 \pm 0.80$ & $-1.76 \pm 0.80$ & $<0.00001^{\mathrm{b}}$ \\
\hline 2.0 years & SDS & $-1.15 \pm 0.87$ & $-0.86 \pm 0.82$ & $-1.04 \pm 0.81$ & $-1.60 \pm 0.81$ & $<0.00001^{\mathrm{b}}$ \\
\hline 3.0 years & SDS & $-1.14 \pm 0.89$ & $-0.86 \pm 0.84$ & $-1.05 \pm 0.83$ & $-1.59 \pm 0.83$ & $0.00002^{\mathrm{b}}$ \\
\hline Change 0-3 & SDS & $0.17 \pm 1.35$ & $-0.30 \pm 1.17$ & $-0.31 \pm 1.10$ & $1.28 \pm 1.16$ & $<0.00001^{\mathrm{b}}$ \\
\hline \multicolumn{7}{|l|}{$P I$ and $B M I$} \\
\hline 0 year & PI (SDS) & $1.57 \pm 3.31$ & $3.86 \pm 2.86$ & $0.66 \pm 2.84$ & $0.17 \pm 2.88$ & $<0.00001^{\mathrm{a}}$ \\
\hline 1 year & BMI (SDS) & $-1.24 \pm 1.23$ & $-0.59 \pm 1.17$ & $-1.40 \pm 1.17$ & $-1.73 \pm 1.10$ & $<0.00001^{\mathrm{a}}$ \\
\hline 3 years & BMI (SDS) & $-1.08 \pm 1.03$ & $-0.55 \pm 0.94$ & $-1.24 \pm 0.94$ & $-1.44 \pm 0.94$ & $<0.00001^{\mathrm{a}}$ \\
\hline Change BMI 1-3 & BMI (SDS) & $0.17 \pm 0.81$ & $0.05 \pm 0.86$ & $0.16 \pm 0.86$ & $0.29 \pm 0.79$ & 0.26 \\
\hline
\end{tabular}

Values are means (SD) which, at age 0.5 until 3 years, were adjusted for gestational age.

$\mathrm{HC}=$ Head circumference; $\mathrm{PI}=$ ponderal index; $\mathrm{BMI}=$ body mass index; SDS = standard deviation score.

* Overall $p$ value is presented of the SGA groups.

Post-hoc testing showed: ${ }^{\text {a }} S G A_{L}$ differed in comparison to the $S G A_{L+W}$ and $S G A_{L+W+H C}$ groups; ${ }^{b} S G A_{L+W+H C}$ differed in comparison to the $\mathrm{SGA}_{\mathrm{L}+\mathrm{W}}$ and $\mathrm{SGA}_{\mathrm{L}}$ groups; ${ }^{\mathrm{c}}$ All groups differed significantly from each other.

highest ponderal index SDS at birth, they had a decrease in weight SDS, especially during the first 6 months, resulting in a normal BMI SDS at age 3 . From age 1 until age 3, $\mathrm{SGA}_{\mathrm{L}+\mathrm{W}}$ and $\mathrm{SGA}_{\mathrm{L}+\mathrm{W}+\mathrm{HC}}$ children showed an increase in BMI (0.16 vs. 0.29 SDS), whereas $S_{G A}$ children remained at the same SDS.

\section{Effect of GH Treatment on Height, Weight and HC}

Mean age $(6.8 \pm 2.3$ years $)$ at start of GH treatment was comparable between the SGA groups $(\mathrm{p}=0.40$, table 3). From 3 years of age until start of GH treatment, height SDS was maintained at a similar level within each group, and did not differ markedly between groups (table 3). GH treatment for 12 months resulted in a similar increase in height SDS (mean increase $=0.86$ SDS) in all groups (fig. 1). In all groups, height SDS after 12 months $\mathrm{GH}$ treatment was significantly $(\mathrm{p}<0.001)$ higher than height SDS at start of treatment and was not different between groups ( $\mathrm{p}=0.35$; table 3 ).

Between 3 years of age and start of GH treatment, weight SDS remained at approximately the same level in all groups (fig. 2 ; tables 2,3 ), with $S_{G A}$ children remaining at a weight SDS of approximately -2.5 SDS which was significantly higher than those in the other two groups 


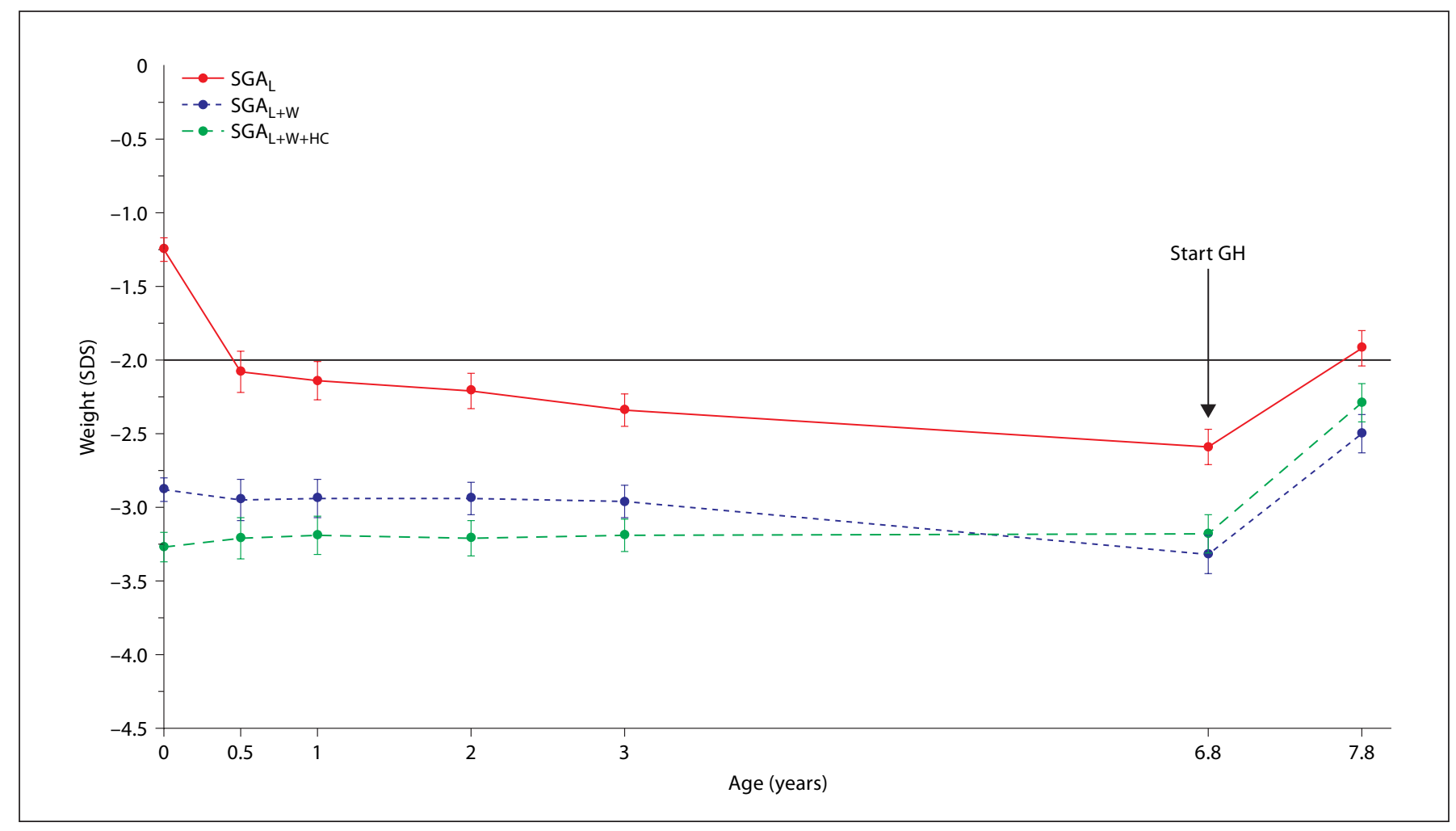

Fig. 2. Weight (SDS) during the first 3 years of life and during 1 year of GH treatment for the short SGA groups. Data shown are means with standard errors.

during this period (tables 2, 3). GH treatment resulted in a significantly greater increment in weight SDS for the $\mathrm{SGA}_{\mathrm{L}+\mathrm{W}+\mathrm{HC}}$ children than the $\mathrm{SGA}_{\mathrm{L}}$ children $(\mathrm{p}=0.02$; table 3).

At start of GH treatment, HC SDS was significantly greater in $\mathrm{SGA}_{\mathrm{L}}$ children than in $\mathrm{SGA}_{\mathrm{L}+\mathrm{W}}$ or $\mathrm{SGA}_{\mathrm{L}+\mathrm{W}+\mathrm{HC}}$ children ( $\mathrm{p}=0.002$; table 3 ; fig. 3 ). GH treatment resulted in a similar increase in $\mathrm{HC}$ in all groups (table 3). Despite this increase, $\mathrm{HC}$ remained the smallest for $\mathrm{SGA}_{\mathrm{L}+\mathrm{W}+\mathrm{HC}}$ and $\mathrm{SGA}_{\mathrm{L}+\mathrm{W}}$ children after 1 year of $\mathrm{GH}$ treatment at -1.12 SDS and -0.88 SDS in comparison with the children in the $\mathrm{SGA}_{\mathrm{L}}$ group, being $-0.46 \mathrm{SDS}(\mathrm{p}=0.001)$.

At start of GH treatment, the sitting height to height ratio was not statistically significant between the groups, $\mathrm{SGA}_{\mathrm{L}}$ children having a mean (SD) of 1.42 (1.63) SDS, $\mathrm{SGA}_{\mathrm{L}+\mathrm{W}}$ children 1.33 (1.22) SDS, and $\mathrm{SGA}_{\mathrm{L}+\mathrm{W}+\mathrm{HC}}$ children $1.51(1.60)$ SDS $(\mathrm{p}=0.86)$.

\section{Parental Height}

Parental heights (mother and father) were not significantly different between the SGA groups (table 1). Paren- tal height was lower than average (mother, -0.97 SDS; father, -0.82 SDS, in comparison to 0 SDS, both $p<$ 0.001). Although mean height SDS for mothers of $S G A_{L}$ children (-1.24 SDS) was lower than those of the other SGA groups, there was no statistical difference between the three groups ( $\mathrm{p}=0.09$; table 1$)$. Target height $(\mathrm{TH})$ SDS tended to be the lowest for $\mathrm{SGA}_{\mathrm{L}}$ children $(-0.66$ SDS) and the highest for $\mathrm{SGA}_{\mathrm{L}+\mathrm{W}+\mathrm{HC}}$ children $(-0.29$ SDS), $S_{\text {G }} A_{\mathrm{L}}$ children showing an intermediate pattern at -0.52 SDS. Height SDS corrected for TH SDS was significantly different at birth but not at start of GH treatment (Birth length-TH, Height-TH SDS, table 1). All groups had a height SDS far below their TH SDS (table 1).

\section{Discussion}

The aim of this study was to determine in short SGA children whether differences in birth anthropometrics, with respect to length, weight, and $\mathrm{HC}$, were associated 


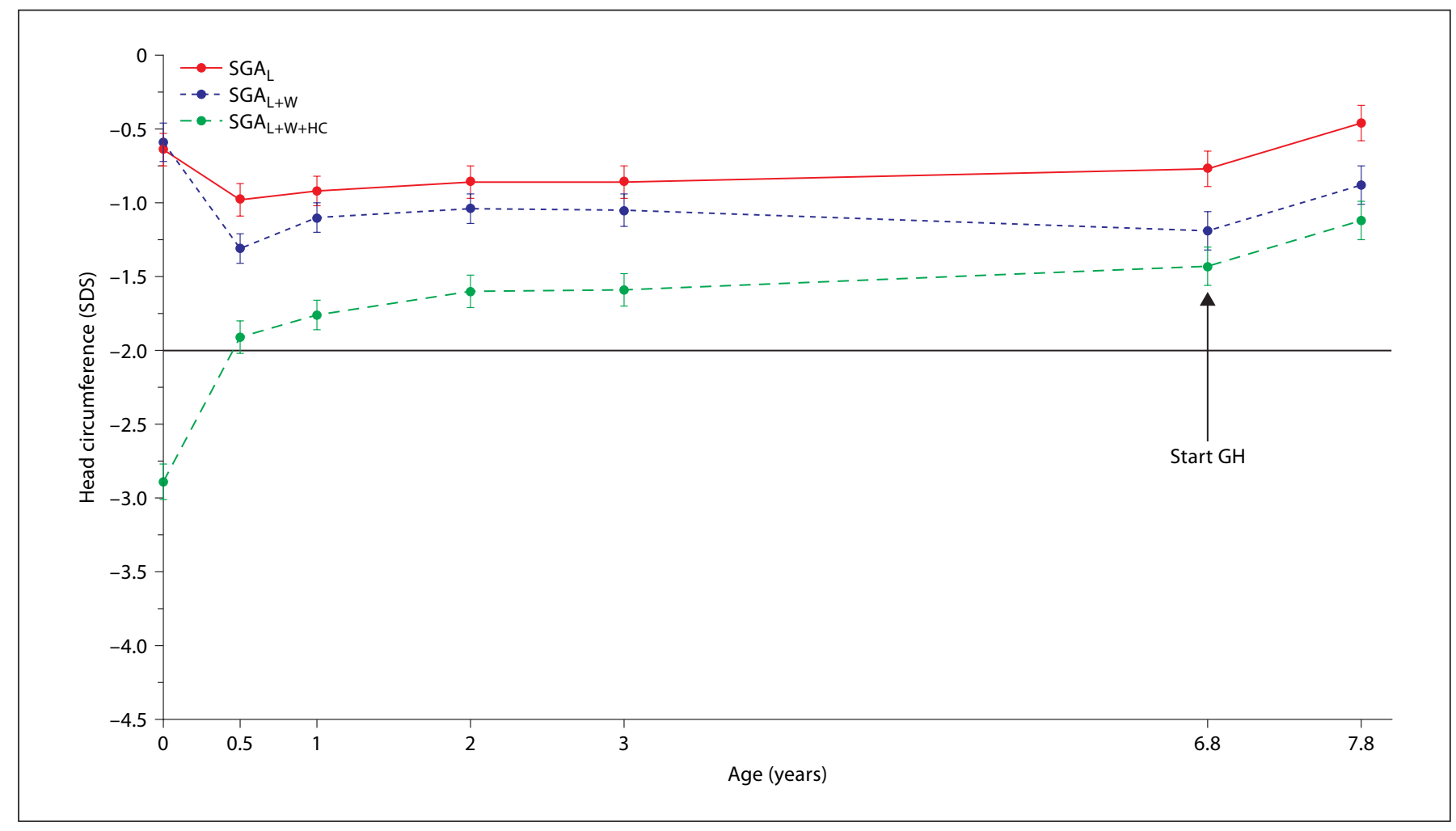

Fig. 3. Head circumference (SDS) during the first 3 years of life and during 1 year of GH treatment for the short SGA groups. Data shown are means with standard errors.

with differences in gestation, type of delivery, postnatal growth, parental height, and response to $\mathrm{GH}$ treatment. Our results show that $\mathrm{SGA}_{\mathrm{L}+\mathrm{W}+\mathrm{HC}}$ children experienced the most severe growth restriction during pregnancy. This is partly explained by their definition to have a length, weight and $\mathrm{HC} \leq-2.00 \mathrm{SDS}$, but was often 1 until 2 SDS below -2.00 SDS. SGA $\mathrm{L}_{+\mathrm{W}}$ children showed an intermediate pattern with regard to birth length and weight in comparison with $\mathrm{SGA}_{\mathrm{L}}$ and $\mathrm{SGA}_{\mathrm{L}+\mathrm{W}+\mathrm{HC}}$ children. Notably, $\mathrm{SGA}_{\mathrm{L}+\mathrm{W}+\mathrm{HC}}$ had the greatest increase in height and $\mathrm{HC}$ during early postnatal life, although at the age of 3 , HC SDS and weight SDS still were significantly lower than those born $\mathrm{SGA}_{\mathrm{L}}$. SGA subclassification could not predict a differential response to $\mathrm{GH}$ treatment as an increased growth was seen for all three groups. After 1 year of treatment however, $\mathrm{HC}$ and weight of $\mathrm{SGA}_{\mathrm{L}+\mathrm{W}+\mathrm{HC}}$ and $\mathrm{SGA}_{\mathrm{L}+\mathrm{W}}$ children remained significantly below those of $S_{\text {GA }}$ children.

$\mathrm{SGA}_{\mathrm{L}}$ children had no postnatal increase in growth, showed a marked decrease in weight and also a decline in HC SDS. In contrast, short SGA $\mathrm{L}_{+\mathrm{W}}$ and $\mathrm{SGA}_{\mathrm{L}+\mathrm{W}+\mathrm{HC}}$ chil- dren had a significant increase in growth during early postnatal life. These differences in postnatal growth patterns might result from different genetic and environmental parameters influencing $\mathrm{SGA}_{\mathrm{L}}$ children as compared with the $\mathrm{SGA}_{\mathrm{L}+\mathrm{W}}$ and $\mathrm{SGA}_{\mathrm{L}+\mathrm{W}+\mathrm{HC}}$ children. $S_{\mathrm{SG}} \mathrm{L}_{\mathrm{W}+\mathrm{HC}}$ children suffered from severely impaired prenatal growth, but experienced a marked increase in growth after birth. In contrast, $\mathrm{SGA}_{\mathrm{L}}$ children were mostly born after a vaginal delivery, were less small at birth and showed a decrease in growth in height and weight after birth. Also, parents of $S_{G A}$ children and especially their mothers, tended to be shorter than those of the other groups. These findings suggest that $\mathrm{SGA}_{\mathrm{L}}$ children resemble a growth pattern as observed in children with idiopathic short stature (ISS) who are also mainly born after a vaginal delivery, have a decreased growth after birth and in many cases short parents. It might well be that subtle skeletal abnormalities play a role in some short $\mathrm{SGA}_{\mathrm{L}}$ children instead of generalized fetal growth restriction, explaining the more frequent vaginal deliveries. For this group of SGA children it might be interesting to 
Table 3. Effect of GH treatment on growth parameters in the total population and in the short SGA groups

\begin{tabular}{|c|c|c|c|c|c|c|}
\hline & & Total & $\mathrm{SGA}_{\mathrm{L}}$ & $\mathrm{SGA}_{\mathrm{L}+\mathrm{W}}$ & $\mathrm{SGA}_{\mathrm{L}+\mathrm{W}+\mathrm{HC}}$ & $\mathrm{p}$ value \\
\hline Sex & boys/girls & $75 / 68$ & $24 / 29$ & $23 / 22$ & $28 / 17$ & 0.24 \\
\hline Age at start & years & $6.81 \pm 2.29$ & $7.12 \pm 2.42$ & $6.49 \pm 2.28$ & $6.79 \pm 2.14$ & 0.40 \\
\hline $\mathrm{GH}$ dose & $\mathrm{mg} / \mathrm{m}^{2} /$ day & $1.11 \pm 0.29$ & $1.10 \pm 0.28$ & $1.13 \pm 0.31$ & $1.09 \pm 0.29$ & 0.76 \\
\hline \multicolumn{7}{|l|}{ Height } \\
\hline Start $^{1}$ & SDS & $-3.04 \pm 0.62$ & $-3.05 \pm 0.62$ & $-3.10 \pm 0.62$ & $-2.96 \pm 0.62$ & 0.54 \\
\hline After 1 year ${ }^{2}$ & SDS & $-2.18 \pm 0.65$ & $-2.25 \pm 0.64$ & $-2.21 \pm 0.64$ & $-2.07 \pm 0.63$ & 0.35 \\
\hline Changes during 1 year ${ }^{2}$ & SDS & $0.86 \pm 0.36$ & $0.81 \pm 0.24$ & $0.89 \pm 0.24$ & $0.89 \pm 0.24$ & 0.13 \\
\hline \multicolumn{7}{|l|}{ Weight } \\
\hline Start ${ }^{1}$ & SDS & $-3.00 \pm 0.92$ & $-2.59 \pm 0.85$ & $-3.32 \pm 0.85$ & $-3.18 \pm 0.85$ & $0.00007^{\circ}$ \\
\hline After 1 year $^{2}$ & SDS & $-2.22 \pm 0.87$ & $-1.92 \pm 0.84$ & $-2.50 \pm 0.84$ & $-2.29 \pm 0.84$ & $0.003^{\mathrm{a}}$ \\
\hline Changes during 1 year ${ }^{2}$ & SDS & $0.78 \pm 0.43$ & $0.67 \pm 0.37$ & $0.82 \pm 0.37$ & $0.88 \pm 0.37$ & $0.02^{\mathrm{b}}$ \\
\hline \multicolumn{7}{|l|}{$\mathrm{HC}$} \\
\hline Start $^{1}$ & SDS & $-1.11 \pm 0.88$ & $-0.77 \pm 0.85$ & $-1.19 \pm 0.85$ & $-1.43 \pm 0.85$ & $0.002^{\mathrm{a}}$ \\
\hline After 1 year ${ }^{2}$ & SDS & $-0.80 \pm 0.92$ & $-0.46 \pm 0.87$ & $-0.88 \pm 0.87$ & $-1.12 \pm 0.87$ & $0.001^{\mathrm{a}}$ \\
\hline Changes during 1 year ${ }^{2}$ & SDS & $0.31 \pm 0.39$ & $0.30 \pm 0.36$ & $0.33 \pm 0.37$ & $0.31 \pm 0.36$ & 0.91 \\
\hline
\end{tabular}

Values are means (SD).

$\mathrm{HC}=$ Head circumference; SDS = standard deviation score.

* Overall $p$ value is presented of the SGA groups.

Post-hoc testing showed: ${ }^{\text {a }} \mathrm{SGA}$ L differed in comparison to the $\mathrm{SGA}_{\mathrm{L}+\mathrm{W}}$ and $\mathrm{SGA}_{\mathrm{L}+\mathrm{W}+\mathrm{HC}}$ groups; ${ }^{\mathrm{b}}$ the $\mathrm{SGA}_{\mathrm{L}}$ group differed from the $\mathrm{SGA}_{\mathrm{L}+\mathrm{W}+\mathrm{HC}}$ group.

${ }^{1}$ Means are adjusted for age at start of $\mathrm{GH}$ treatment.

${ }^{2}$ Means are adjusted for age at start of GH treatment and GH dose.

perform genetic research into genes involved in pre- and postnatal bone development.

$S_{\text {SG }} \mathrm{L}_{\mathrm{W}}$ children were characterized by their intermediate birth size, type of delivery, and postnatal growth pattern in comparison to the $S G A_{L}$ and $S G A_{L+W+H C}$ children. These children also had the highest frequency of gestational hypertension which might explain their short gestational age during elective caesarean section and their spared birth HC. This observation might suggest that $\mathrm{SGA}_{\mathrm{L}+\mathrm{W}}$ children, in contrast to $\mathrm{SGA}_{\mathrm{L}}$ and $\mathrm{SGA}_{\mathrm{L}+\mathrm{W}+\mathrm{HC}}$ children, might be a consequence of gestational hypertension. A previous report also showed that the combination of low birth weight and height is most frequent after gestational hypertension [14], which confirms our observation. We however could not observe that $\mathrm{SGA}_{\mathrm{L}+\mathrm{W}}$ children were more prone to have cardiovascular risk factors as a higher postnatal weight or BMI increase in comparison to the other groups. Further long-term follow-up of $S A_{L+W}$ children is needed to identify a potential higher risk to cardiovascular risk factors.

$\mathrm{SGA}_{\mathrm{L}+\mathrm{W}+\mathrm{HC}}$ children were the smallest at birth, with regard to length, weight and $\mathrm{HC}$. We expected to find a comparable or somewhat smaller birth length SDS than in the other children, as birth length SDS $\leq-2.00$ was the major inclusion criterion for all children in the study cohort. However, we found that $\mathrm{SGA}_{\mathrm{L}+\mathrm{W}+\mathrm{HC}}$ children had a considerably shorter birth length than $S_{G A}$ and $S G A_{L+W}$ children, despite of having the highest target height of the groups. Interestingly, $\mathrm{SGA}_{\mathrm{L}+\mathrm{W}+\mathrm{HC}}$ children had the greatest increase in growth parameters of all groups, indicating that $\mathrm{SGA}_{\mathrm{L}+\mathrm{W}+\mathrm{HC}}$ children might have had the most severe fetal growth restraint which disappeared after birth. Postnatal growth of the children with the most severe growth retardation might be explained by regression to the mean. However, if this growth would be due to regression to the mean then we would have expected growth of all growth parameters in the $\mathrm{SGA}_{\mathrm{L}+\mathrm{W}+\mathrm{HC}}$ children. As there was no growth in weight, we suspect that regression had only a limited effect.

Of note was the finding that $68 \%$ of $S G A_{L+W+H C}$ children were delivered by caesarean section in contrast to $S_{\text {GA }}$ children of whom $76 \%$ were born after vaginal delivery. It is likely that the $\mathrm{SGA}_{\mathrm{L}+\mathrm{W}+\mathrm{HC}}$ children experienced growth retardation from early in pregnancy, also 
affecting head growth. It might well be that the percentage of deliveries by elective caesarean section was high due to this severe growth retardation which is often seen in combination with reduced placental blood flow.

Phenotypic variation is by definition determined by the interaction between genetic and environmental factors. Currently most genetic research in short SGA children is focused on the role of the insulin-like growth factor-I (IGF-I), IGF-I receptor (IGF-IR) and GH receptor genes in determining size at birth [15-21]. Of particular interest is the finding that patients with mutations in the IGF-I or IGF-IR genes also had a reduced HC and various degrees of mental retardation $[15,17-19]$. SGA $A_{L+W+H C}$ children showed, however, a combination of severe prenatal growth restraint and remarkable postnatal growth in height and HC, which is not a characteristic of subjects with a deletion or mutation in the IGF-I or IGF-IR gene. For that reason, it is unlikely that $\mathrm{SGA}_{\mathrm{L}+\mathrm{W}+\mathrm{HC}}$ children have major deletions in these genes but minor variants might play a role. Further research into gene-gene and gene-environment interactions is needed to elucidate the

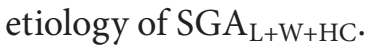

Evidence from several studies suggests that pre- and postnatal $\mathrm{HC}$ growth may influence cognitive function in SGA children [22-24]. For example, SGA children with reduced $\mathrm{HC}(\leq \mathrm{P} 10)$ at birth and at 9 months of age experienced widespread impairments in their verbal and nonverbal IQ ratings, phonological awareness skills, visual-motor integration skills, problem-solving abilities and literacy skills at age 7-9 [23]. Other studies have shown that SGA children with a reduced height and/or insufficient growth in $\mathrm{HC}$ and/or height had the highest risk for subnormal intellectual and psychological performance $[22,24,25]$. Hence identification of short SGA children with small HC SDS may be clinically relevant as it may help to identify children at particular risk for learning difficulties.

In this study, we have specifically evaluated SGA children with persistent short stature, in contrast to SGA catch-up children, having a height $<-2.00$ SDS at 3 years of age. As a first step in subphenotyping the heterogeneous SGA group, we have focused on short SGA children as they receive endocrine care for their growth retardation, often including GH treatment.

In conclusion, our study suggests that SGA children with persistent short stature may be subclassified according to their birth length, weight and HC. Subclassification using these criteria may provide a useful framework to explore the mechanisms underlying differences in the extent of spontaneous postnatal growth that are observed in a population of short SGA children. Such a subclassification of short SGA children might also be useful for elucidating underlying genetic or environmental causes of SGA and future risk profiles with regard to adult diseases. Where $\mathrm{SGA}_{\mathrm{L}}$ children appeared to experience the least fetal growth retardation and postnatal height increment as within ISS children, $\mathrm{SGA}_{\mathrm{L}+\mathrm{W}}$ children were most affected by gestational hypertension which might suggest effects on cardiovascular risk profiles in later life. $\mathrm{SGA}_{\mathrm{L}+\mathrm{W}+\mathrm{HC}}$ children were born with the lowest $\mathrm{HC}$ but experienced a major increase in $\mathrm{HC}$ growth postnatally. In this group of children, further studies might be directed at specialized interventions such as remedial teaching on cognition during early infancy as well as evaluating the effect of GH treatment at an earlier age.

\section{Acknowledgements}

We thank the children and their families who agreed to take part in this study and we thank J. van Nieuwkasteele, E. Lems, M. Huibregtse, J. Bruinings, J. van Houten, research nurses for their technical assistance and help with data collection. We also thank K. van Dinteren and D. Assink, research assistants, for their help with data collection. The participating physicians of the original GH trials were: H. Reeser, Juliana Children's Hospital, The Hague; J. Waelkens, Catharina Hospital, Eindhoven; M. Jansen, Wilhelmina Children's Hospital, Utrecht; E. Houdijk, P. Voorhoeve, Free University Hospital Amsterdam; R. Odink, W. Bakker-van Waarde, Beatrix Children's Hospital, Groningen; J. Mulder, Rijnstate Hospital, Arnhem; C. Rongen-Westerlaken, Canisius-Wilhelmina Hospital, Nijmegen; B. Bakker, University Medical Center Leiden; B. Otten, C. Noordam, University Medical Center Sint Radboud, Nijmegen; E. Sulkers, Hospital Walcheren, Vlissingen; J. van der Hulst, Zaans Medical Center, Zaandam; A. HokkenKoelega, Erasmus MC-Sophia Children's Hospital, Rotterdam, The Netherlands.

References

1 Hokken-Koelega AC, De Ridder MA, Lemmen RJ, Den Hartog H, De Muinck KeizerSchrama SM, Drop SL: Children born small for gestational age: do they catch up? Pediatr Res 1995;38:267-271

2 Albertsson-Wikland K, Karlberg J: Natural growth in children born small for gestational age with and without catch-up growth. Acta Paediatr 1994;399(suppl):64-71.

3 European Health For All Database (HFADB). Available at: www.euro.who.int/hfadb

4 Arends NJ, Boonstra VH, Hokken-Koelega AC: Head circumference and body proportions before and during growth hormone treatment in short children who were born small for gestational age. Pediatrics 2004; 114:683-690. 
5 Sas TC, Gerver WJ, de Bruin R, Mulder PG, Cole TJ, De Waal W, Hokken-Koelega AC: Body proportions during 6 years of $\mathrm{GH}$ treatment in children with short stature born small for gestational age participating in a randomised, double-blind, dose-response trial. Clin Endocrinol (Oxf) 2000;53:675681.

-6 Sas T, Mulder P, Hokken-Koelega A: Body composition, blood pressure, and lipid metabolism before and during long-term growth hormone treatment in children with short stature born small for gestational age either with or without growth hormone deficiency. J Clin Endocrinol Metab 2000;85: 3786-3792.

7 Sas T, Mulder P, Aanstoot HJ, Houdijk M, Jansen M, Reeser M, Hokken-Koelega A: Carbohydrate metabolism during long-term growth hormone treatment in children with short stature born small for gestational age. Clin Endocrinol (Oxf) 2001;54:243-251.

-8 Van Pareren Y, Mulder P, Houdijk M, Jansen M, Reeser M, Hokken-Koelega A: Adult height after long-term, continuous growth hormone treatment in short children born small for gestational age: results of a randomized, double-blind, dose-response growth hormone trial. J Clin Endocrinol Metab 2003;88:3584-3590.

-9 Van Pareren YK, Duivenvoorden HJ, Slijper FS, Koot HM, Hokken-Koelega AC: Intelligence and psychosocial functioning during long-term growth hormone therapy in children born small for gestational age. J Clin Endocrinol Metab 2004;89:5295-5302.

10 Usher R, McLean F: Intrauterine growth of live-born Caucasian infants at sea level: standards obtained from measurements in 7 dimensions of infants born between 25 and 44 weeks of gestation. J Pediatr 1969;74:901910 .
11 Fredriks AM, van Buuren S, Burgmeijer RJ, Meulmeester JF, Beuker RJ, Brugman E, Roede MJ, Verloove-Vanhorick SP, Wit JM: Continuing positive secular growth change in The Netherlands 1955-1997. Pediatr Res 2000;47:316-323.

12 Gerver WJ, de Bruin R: Paediatric Morphometrics, a Reference Manual, ed 2. Maastricht, University Press Maastricht, 2001.

13 Roede MJ, van Wieringen JC: Growth diagrams 1980: Netherlands Third Nationwide Survey. Tijdschr Soc Gezondheidsz 1985; 63(suppl):1-34.

14 Mamelle N, Boniol M, Riviere O, Joly MO, Mellier G, Maria B, Rousset B, Claris O: Identification of newborns with fetal growth restriction in weight and/or length based on constitutional growth potential. Eur J Pediatr 2006;165:717-725.

15 Woods KA, Camacho-Hubner C, Savage $\mathrm{MO}$, Clark AJ: Intrauterine growth retardation and postnatal growth failure associated with deletion of the insulin-like growth factor I gene. N Engl J Med 1996;335:13631367.

16 Johnston LB, Dahlgren J, Leger J, Gelander L, Savage MO, Czernichow P, Wikland KA, Clark AJ: Association between insulin-like growth factor I polymorphisms, circulating insulin-like growth factor I, and pre- and postnatal growth in two European small for gestational age populations. J Clin Endocrinol Metab 2003;88:4805-4810.

17 Walenkamp MJ, Karperien M, Pereira AM, Hilhorst-Hofstee Y, van Doorn J, Chen JW, Mohan S, Denley A, Forbes B, van Duyvenvoorde HA, van Thiel SW, Sluimers CA, Bax JJ, de Laat JA, Breuning MB, Romijn JA, Wit JM: Homozygous and heterozygous expression of a novel insulin-like growth factor-I mutation. J Clin Endocrinol Metab 2005;90: 2855-2864.

-18 Abuzzahab MJ, Schneider A, Goddard A, Grigorescu F, Lautier C, Keller E, Kiess W, Klammt J, Kratzsch J, Osgood D, Pfäffle R, Raile K, Seidel B, Smith RJ, Chernausek SD, Intrauterine Growth Retardation (IUGR) Study Group: Insulin-like growth factor I receptor mutations resulting in intrauterine and postnatal growth retardation. $\mathrm{N}$ Engl J Med 2003;349:2211-2222.
19 Kawashima Y, Kanzaki S, Yang F, Kinoshita T, Hanaki K, Nagaishi J, Ohtsuka Y, Hisatome I, Ninomoya H, Nanba E, Fukushima T, Takahashi S: Mutation at cleavage site of insulin-like growth factor receptor in a short-stature child born with intrauterine growth retardation. J Clin Endocrinol Metab 2005;90:4679-4687.

20 Dos Santos C, Essioux L, Teinturier C, Tauber M, Goffin V, Bougneres P: A common polymorphism of the growth hormone receptor is associated with increased responsiveness to growth hormone. Nat Genet 2004;36:720-724.

21 Arends N, Johnston L, Hokken-Koelega A, van Duijn C, de Ridder M, Savage M, Clark A: Polymorphism in the IGF-I gene: clinical relevance for short children born small for gestational age. J Clin Endocrinol Metab 2002;87:2720

22 Lundgren EM, Cnattingius S, Jonsson B, Tuvemo T: Intellectual and psychological performance in males born small for gestational age with and without catch-up growth. Pediatr Res 2001;50:91-96.

23 Frisk V, Amsel R, Whyte HE: The importance of head growth patterns in predicting the cognitive abilities and literacy skills of small-for-gestational-age children. Dev Neuropsychol 2002;22:565-593.

24 Brandt I, Sticker EJ, Lentze MJ: Catch-up growth of head circumference of very low birth weight, small for gestational age preterm infants and mental development to adulthood. J Pediatr 2003;142:463-468.

-25 Gale CR, O’Callaghan FJ, Godfrey KM, Law $\mathrm{CM}$, Martyn CN: Critical periods of brain growth and cognitive function in children. Brain 2004;127:321-329. 